\title{
Obraz siedemnastowiecznej Polski i jej mieszkańców w oczach cudzoziemców
}

Weronika Girys-Czagowiec 


\title{
Weronika Girys-Czagowiec
}

\section{Obraz siedemnastowiecznej Polski i jej mieszkańców w oczach cudzoziemców}

\begin{abstract}
Przybywali zawsze. Nie brakło ich nigdy. (...) Byli między nimi blędni rycerze, przemyślni kupcy, dostojni legaci papiescy, wojownicy i lekarze, którzy w słuzbę polskich dworów zamierzali wstąpić, agenci, którzy zdradzieckie cele swe ukrywali i zwykli ruchliwi turyści. (...) Przypatrywali się, słuchali, pisali'.
\end{abstract}

Cudzoziemcy przybywający do Polski w XVII wieku raczej nie kierowali się modą, ów „pólnocny kraj” nie znajdował się bowiem wówczas na szlaku modnycl państw. Przybysze z zagranicy zazwyczaj udawali się do Polski w celu zrealizowania konkretnych misji, w poszukiwaniu zarobku. Z rzadka tylko cudzoziemcy odwiedzali nasz kraj z prostej ciekawości.

Ich spostrzeżenia koncentrowały się przede wszystkim wokół kontrastów kulturowych i ustrojowych; uwagę podróżnych zwraca wszak glównie to, co różni odwiedzany kraj od ich ojczyzny. Należy podkreślić, ze XVII wiek to czas, w którym owe różnice między Rzeczpospolitą a Francją, Anglią czy Niderlandani zarysowywały się szczególnie wyraźnie. Jak zauważa Janusz Tazbir, wynikało to z dysproporcji narastających między Polską a innymi krajami, z nierównomiemości w rozwoju spolecznym wyżej wymienionych państw $^{2}$. Przetom XVI i XVII wieku przynióst w wiclu krajach europejskich wzrost sił mieszczaństwa i ugruntowanie absolutnej wladzy królewskiej. Zmienialy się prawa i obyczaje. Jak pisze Maria Bogucka:

'M. Smolarski. Dan'ma Polsku u' opisad cudzozicmón'. Warszawa 1958, s. 5.

'J. Tazbir. Kultura szladecka w' Polsce. Rozku'it - upudek - relikty. Poznań 1998, s. 162. 
doskonalił się system rządzenia, kruszaly przestarzałe feudalne przywileje. Absolutni wladcy rozporządzali sprawnie działającym aparatem urzędniczym. Świat kroczył nieustannie naprzód, odrzucając to wszystko, co było pozostałością minionych epok i hannowało jego rozwój. (...) Wśród potężniejących, sprężyście zarządzanych państw Rzeczpospolita była tworem coraz bardziej archaicznym

Ogół szlachty polskiej jednakże nie widział potrzeby zmian ustrojowych w Rzeczpospolitej. Przeciwnie, wyrażał przekonanie, że swoistego modelu ustrojowego należy bronić przed zmianami. Wrogów Polski widziano więc nie tylko poza jej granicami, lecz także wewnątrz państwa; byli to przeciwnicy złotej wolności szlacheckiej, o której wiele pisali przybysze $z$ innych krajów. Cudzoziemców interesowały równiez inne aspekty życia w Polsce, warto zatem przyjrzeć się obrazowi siedemmastowiecznej Rzeczpospolitej, który wyłania się $z$ ich relacji ${ }^{+}$.

Podróżując po naszym kraju, raczej nie chwalili warunków, w jakich odbywały się owe wyprawy. Nierzadko zdarzało się bowiem, że musieli znosić niedogodności związane ze zlymi noclegami i takim samym pożywieniem. Duże znaczenic miała też pora roku, w której udawano się w podróż po Polsce. Srogie zimy i błoto podczas roztopów czyniły jazdę dodatkowo uciążliwą, zważywszy fatalny stan polskich dróg i mostów. Henryk Michał Hysrle, czeski magnat, wojskowy w służbie I Iabsburgów, w 1604 roku przekraczal polską granicę ,wśród zamieci i mrozów trzaskających”, podkreślając w swojej relacji „wielkie zimno" panujące w Polsce. Ulryk von Werdum, który podróżował po naszym kraju w latach 1670-1672, i jak pisze Xawery Liske, ,admiracji (...) dla Polski i jej ludności nie wyniósł ze swego dwuletniego pobytu w tym kraju"7, uskarżał się na niezwykle twardy styczniowy mróz i „,bezdenne śniegi”. Podkreślal zly stan mostów i błotnistych dróg; pisał, iż w żadnym mieście nie ma dobrego bruku, choć kamienie leżą gęsto na polach" W. Wplynęlo to zapewne na jego opinię o Polakach, których uznat za "naród nie dość pracowity i staranny”," niedbaly i niechlujny.

Niezbyt pochlebne dla naszego kraju okazują się także rady, których udzielal podróżującym po Polsce Gaspar de Tende, przebywający na dworze króla Jana Kazimierza aż do jego abdykacji. Jak zauważa Jan Antoni Wilder, spostrzeżenia poczynione przez niego w drugiej

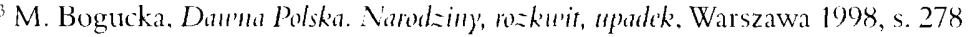

+ Ninicjszy tekst dotyczy w duzej mierze spostrzezeń obcokrajowców na temat szlachty, jako że ta grupa odgrywała wówczas przcomożną rolç wv państwic polskim.

'Cudzoziemoy' o Polsce. Relacje i opinie, opr. J. Cintel. t. 1: II 'iek X-XI'II, Kraków 1971, s. 209.

"Ibide'll.

'K. Liske, Cindzoziemcy' "Polsce, Lwów 1876, s. 76.

"Ibidem, passim.

"Ibide'm, s. 7 o.

"Ibide'm.
} 
połowie XVII wieku nie odbiegają od uwag wcześniejszych o blisko sto lat. Sposób podróżowania po naszym kraju nie zmienił się zatem przez ten czas". Oto niektóre z uwag Gaspara de Tende, świadczące o tym, co raziło francuskiego szlachcica:

Brak przede wszystkim w Polsce gospód lub zajazdów, w których można by wygodnie umieścić się i otrzymać łóżko. Znajdują siç tam zwykle drewniane budynki zwane „karczmami”, w których trzeba niejednokrotnie ulokować się obok koni, krów i świní, w dhugiej stajni skleconej ze źle spojonych desek i krytej słomą. W głębi tej stajni jest zwykle izba z piecem, ale nie można tam mieszkać w lecie z powodu much, pcheł, pluskiew oraz fetorów. Nawet przy dużych upałach okna pozostają tam zamkniçte'?

Radził on podróżnym, aby zabierali ze sobą łóżko z materacem, pierzynę, prześcieradlo, poduszki i siennik. Przed wyprawą należalo również przygotować zapasy piwa, wina i wódki, chleba i pieczonego mięsa oraz świec. Nie wolno było zapomnieć o zabraniu owsa dla koni i tłuszczu do smarowania kół. Natomiast wybierając się w podróż zimą, należało zaopatrzyć się w futro i wódkę, jako że ostre mrozy były trudne do zniesienia.

Nasilanie się krytycznych opinii o warunkach podrózowania po Polsce wiązało się z faktem, iż w Europie Zachodniej od XVI wieku władze państwowe dbaly o budowę i utrzymywanie dróg. Wzrost centralizacji władzy wiązał się bowiem z koniecznością stworzenia dogodnych warunków do stalego kontaktowania się ze wszystkimi częściami krajı. Udogodnienia komunikacyjne byly niezmiernie ważne także dla przewożących towary kupców, toteż i miasta zajmowały się budową i konserwacją dróg. Równocześnie wraz z podnoszeniem się poziomu życia codziennego wzrastały wymagania, zatem konkurujący ze sobą whaściciele zajazdów dbali o wygodę podróżnych ${ }^{13}$. Tymczasem panujące w siedemnastowiecznej Polsce warunki podróży nie zmienialy się zasadniczo od stuleci, dlatego przybysze z zagranicy zmuszeni byli do korzystania ze zlych dróg i zatrzymywania się w prymitywnych zajazdach. W takiej sytuacji

musiała powstać duża rozpiętość między warunkanni podróżowania w Polsce i większości krajów zachodnioeuropejskich. O różnicy tej wiedziano za granicą (...) dokładniej niż sobie u nas zdawano z tego sprawę. W rezultacie, niewygody związane z podróżowaniem po Polsce staly się w pewnych kołach niemal przyslowiowe $(\ldots)^{14}$.

"J. A. Wilder. Okic'm cudzusiemca, Warszawa 1959, s. 39.

I' Cudzozicme's o Polsce'..., op. cit., s. 329.

${ }^{13}$ Zob. J. A. Wilder, op. cit., s. $4+46$.

${ }^{1+}$ Ibidem, s. +7 . 
O ile cudzoziemcy, zatrzynując się w zajazdach, byli narażeni na przykrości doznawane ,jeśli nie od ludzi, to z powodu (...) strasznie złych noclegów”"5. o tyle w szlacheckich siedzibach byli oni witani bardzo chętnie, i zazwyczaj slawili polską gościnność. Szlachta dysponowała wolnym czasem niekiedy nawet $w$ nadmiarze $\mathrm{i}$ byla spragniona informacji, jako ze dwory byly od siebie znacznie oddalonete, totez zwykle cieplo witala w swych progach Anglika, Francuza czy Wlocha. Jak zauważa Maria Ossowska,

gdzie jest co jeść, gdzie jest zwierzyna i gdzie ludzie nie mają co robić, gościnność jest cnota. k tórą z góry można przewidziećn ${ }^{17}$.

Jednym z zagranicznych podróżnych, którzy chwalili ową polską cnotę, byl Guillaume de Beauplan, francuski inżynier i kartograf. Spędził on w Polsce siedemnaście lat i uważał jej mieszkaníców za ludzi "gościmnych nad wszystkie wyrazy”" , jako że przyjmowali oni $z$ atencją nie tylko swych przyjaciól, lecz także obcych przybyszy z zagranicy. Podobne spostrzeżenia poczynil Gaspar de Tende, który pisal:

Polska szlachta jest z natury bardzo uprzejma. Kiedy cudzoziemcy przejeżdżają przez jej kraj, zapraszają ich, by wypili i wypoczęli u nich, a goszczą ich, jak mogą najlepiej. Znatem takich, którzy gościli u siebie zupełnie nieznanych im Francuzów, Wlochów czy Niemców (... ${ }^{19}$.

Jednakże przepych i rozrzutność, które cudzoziemcy obserwowali podczas pobytu w szlacheckich i magnackich dworach, budzily ich zdumienie. Wedlug Beauplana polskie biesiady przewyższały wystawnością uczty, które widział w innych krajach, zadziwial go również przebieg owych biesiad. Okazalość i przepych, w których lubowała się polska szlachta, zauważal także Bernard O'Connor, który w 1694 roku przebywał w naszym kraju jako lekarz króla Jana III Sobieskiego.

W relacjach zagranicznych podróżnych znalazly się obszerne opisy uczt trwających wiele godzin, komentarze dotyczące potraw, a także uwagi na temat obowiązujących ceremoniałów i zachowania biesiadników. Okazuje się, że przy calej wystawności szlacheckich biesiad podawane tam potrawy często spotykaly się z krytyką cudzoziemców, jako że byly obficie przyprawiane pieprzem, imbirem, szafranem, goździkami i cynamonem ${ }^{21)}$. Z relacji Jeana de Labourera, który w 1646 roku przybył do Polski wraz z orszakiem Marii Ludwiki,

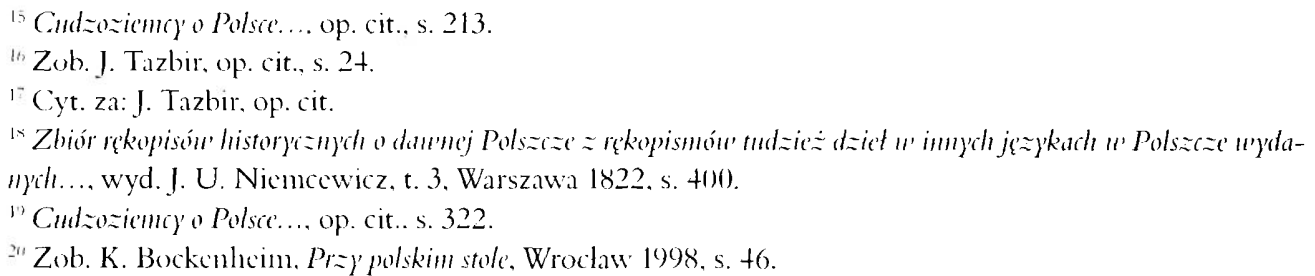


wynika, że choć starannie przygotowane potrawy „nęcily oczy i podniebienie”, to jednak Francuzi tracili apetyt wkrótce po ich skosztowaniu ${ }^{21}$. Stone i korzenne potrawy nie odpowiadały również Ulrykowi de Werdum. Podkreślał on wprawdzie, że wszystko, co jest niezbędne do życia, znajduje się w Polsce w obfitości i za niewysoką cenę, ale nie był dobrego zdania o polskiej kuchni. Oto, co o niej pisat:

W calej Polsce nie znajdziesz prawie chleba dobrze wypieczonego, a gotowane mięso żrą (...) także prawie surowe, pieczone zaś zwykle spalone. (...) Jak we wszystkim zaś, tak i w gotowaniu są Polacy bardzo niechlıjni. (...) Soli i wszelkiego rodzaju korzeni żaden naród nie używa tak obficie, jak Polacy ${ }^{22}$.

Dla cudzoziemców, którym nie słuzyło polskie jedzenie, szczególnie kłopotliwy okazywał się ceremonial wznoszenia toastów, związany z przepijaniem do każdego biesiadnika po kolei. Ów obyczaj, o którym wspominali Jean de Laboureur, Guillaume de Beauplan czy Franciszek Paulin Dalerac (sekretarz Marii Kazimiery), nie budził aprobaty gości z zagranicy, ponieważ sprzyjał szybkiemu upijaniu się ucztujących. Jak pisał Beauplan, pewną miarę w piciu zachowywali tylko ci, którym powierzono opiekę nad srebrną zastawą. Szczególnie wiele do życzenia pozostawiały jego zdaniem obyczaje slużby, która dopuszczała się zachowań wprost grubiańskich,

wycierając brudne i zatłuszczone talerze w tapety, choćby nie wiem jak były piękne i kosztowne, lub też w odrzucone wyloty kontuszów ich panów, bez żadnych względów dla ich pięknych ubiorów ${ }^{23}$.

Mniej krytycznie o polskiej kuchni i obyczajach Polaków wyrażat się Gaspar de Tende, który chwalił potrawy przyrządzone z cielęciny i wolowiny, zupy rybne i jarzyny oraz stwierdzał, że „Polacy, a zwłaszcza ludzie wykwintni, jedzą w sposób bardzo przyzwoity, nie dotykają nigdy potraw rękami"-2t. I on jednak zauważył, że drzwi sali, w której odbywala się biesiada, zamykano na klucz do momentu, w którym zebrano ze stołu cale srebro, „w innym wypadku służba niejedıą sztukę by zabrała”-25.

Zdumiewające swą okazałością uczty nierzadko budziły krytykę cudzoziemców. Dostrzegali oni ogólną skłonność polskiej szlachty do przepychu i wystawności, przejawiającą się także w upodobaniu do bogatych, barwnych strojów, inspirowanych modą orientalną. Relacje podróżników z innych państw zawierają liczne opisy ubiorów o zadziwiającym prze-

\footnotetext{
${ }^{21}$ Cudzozicmey' Polsce.... op. cit., s. $2+2$.

Ibide'm. s. 298.

${ }^{23}$ Ibidem. s. 272.

${ }^{2+}$ Ibidem, s. 329.

Ibide'm. s. 32x.
} 
pychu. Według Labourera szlachta, witająca wjeżdzającą do Gdańska królową Marię Kazimierę, prezentowała się wprost olśniewająco. Dwustu szlachciców, pochodzących z najznakomitszych polskich rodzin, miato na sobie szaty za złotogłowiu perskiego lub aksamitu, podbite „futrami bezcennej wartości, były tam bowiem grzbiety sobolowe i panterze, które tym droższe są od soboli, im więcej skóra ich posiada cętków"26. Pod dolmanami, krótkimi płaszczami zarzucanymi zazwyczaj na lewe ramię, nosili żupany, „prawie wszystkie z materiału zlotolitego lub brokatu, złota, srebra lub jedwabiu z kwiatami, wyhaftowanymi iglą rękami dam tego kraju"27. Stroju dopelnialy nakrycia glowy z kunich futer, ozdobione kitami z piór przypiętych brylantami. Aby opisać konie, okryte drogocennymi tkaninami i przystrojone zlotem oraz klejnotani, Laboureur przywoluje stowa Wergiliusza z siódmej księgi Eneidy, malujące dary króla Lacjum Latynusa dla Eneasza (Aen. VII, 275-279):

Przy żłobach stało trzysta koni okazalych,

Każe rzędem prowadzić: ubiór ich bogaty,

Wiszą pyszne kobierce i drogie szkarłaty,

Złote łańcuchy nisko piersi opasuja,

Zlotem okryte, zloto pod zębami żują ${ }^{2 \aleph}$.

Cudzoziemców zdumiewały także przepych i orientalna egzotyka strojów polskich dyplomatów, podróżujących do krajów europejskich. Przez wieki przetrwała legenda wjazdu polskiego poselstwa do Rzymu. Celem podjętej w 1633 roku misji Jerzego Ossolińskiego było okazanie wierności papieżowi Urbanowi VIII w inienin króla Wladysława IV. Wschodni przepych trzystuosobowego orszaku olśnil mieszkańców Rzymu, podziwiających stroje ze srebrnej tureckiej lamy, konie gubiące zlote podkowy, wielbłądy. Imponujący, choć skromnicjszy, był także wjazd polskiego poselstwa do Paryża w 1645 roku; na czele tej misji stal Krzysztof Opaliński. Relację z owego zdarzenia zawdzięczanny Franciszce de Moteville, która pisała, iz Polacy zaprezentowali

ten dawny przepych, który od Medów przeszedł do Persów. Lubo dawni Sarmaci nie słynęli nigdy ze zbytków, potomkowie ich atoli, sąsiedzi Turków, przepych i okazałość serajów naśladować zdają się. Widać w nich jeszcze niejakie ślady dawnej ich azjatczyzny ${ }^{29}$.

Podobnie Jean de Laboureur przyrównal wystawność polskiej szlachty do bogactw i zbytku dawnych Persów.

2" Ibidem, s. 244 .

${ }^{27}$ Ilide'm.

2N Tl. F. K. Dnrochowski; cyt. za: Cudzosiemcy o Polsce...., op. cit., s. 258.

"Cyt. za: M. Możdżyíska-Nawotka. O modadh i strojach, Wrodaw 2002, s.88. 
Orientalizm polskiego ubioru był zatem tą cechą, która szczególnie zwracała uwagę cudzoziemców. W zachodniej Europie ugruntowało się przekonanie. że Polska to egzotyczny kraj, którego mieszkańcy lubują się we wschodıim przepychu. Stąd też podczas maskarad urządzanych na europejskich dworach, gdzie chętnie występowano w przebraniu Arabów, Persów, Chińczyków, Turków, Indian czy Murzynów, można było spotkać również stroje sarmackie. W ten sposób zaliczano Polskę w poczet ludów barbarzyńskich, wobec których odczuwano wyższość.

Należy bowiem podkreślić, że polska wystawność budziła zachwyt przede wszystkim wśród .,pospólstwa, lubiącego barwne i egzotyczne widowiska”30, natomiast dla ludzi oświeconych była raczej przejawem marnotrawienia pieniędzy. W krajach Europy Zachodnicj pieniądz odgrywał bowien inną rolę niż w naszym kraju. Jak pisze Janusz Tazbir,

w Anglii czy Niderlandach byl lokowany w rozliczne przedsiębiorstwa typu wczesnokapitalistycznego, których brakowało u nas. Tam zaczyna się - częściowo pod wpływem reformacji - gloszenie makazu oszczędności. Hasła ograniczania potrzeb, unikania wystawnych uczt, skrzętnego gromadzenia kapitalów są wcielane w życie przede wszystkim przez powstające pod wpływem ideologii purytańskiej mieszczaństwo holenderskie lub angielskie, na którym wzorıje się nowa szlachta. W Rzeczypospolitej natomiast patrycjat swą rozrzutnością stara się często dorównać szlachcie, nawet ariańscy przedstawiciele tej warstwy nie stronią w XVII wieku od zbytkownych przyjęc ${ }^{31}$.

Trudno się zatem dziwić, że cudzoziemcy ze zgorszeniem obserwowali nicktóre zachowania polskicj szlachty, takie jak powszechne podczas biesiad thuczenie o glowę kosztownych kielichów.

Charakter narodowy owych rozmilowanych w zbytkach mieszkańców epólnocnego kraju" przedstawia bardzo złożone zjawisko. Z jednej strony określani są oni przez przybyszów z innych państw jako ludzie dobrzy, szczodrzy, gościnni i pelni pogody ducha. Guillaume de Beauplan postrzegał Polaków również jako lıdzi pozbawionych uszczypliwości i mściwości, nierzadko zdolnych do wielkich czynów. Doceniał też ich męstwo, odwagę i rycerskość, podobnie jak pan Payen, o którym wiadomo niewiele ponad to, iz byl wyzszym urzędnikiem królewskim, a swą książkę zadedykował ministrowi spraw zagranicznych króla Ludwika XIV. Nie są też blizej znane okoliczności jego pobytu w Polsce około roku 1660. Ów podróżnik nakreślił jednakże i inny wizerunck mieszkańców naszego kraju - ludzi zuchwałych, popędliwych i nickiedy brutalnych. Zdecydowanie negatywną opinię o Polakach zawarł w swej relacji Ulryk von Werdum, wedlug którego Polaków cechowały lekkomyślność i niestałość. Nie cenił wysoko mieszkańców Rzeczypospolitej, nznając ich

\footnotetext{
3.) J. Tazbir. op. cit., s. 170.

"Ibide'm, s. 170-171.
} 
za ludzi niedbałych i leniwych, którym „na zręczności rozumu także (..) nie zbywa”32. Gaspar de Tende zaś był zdania, że gdyby Polacy unieli przestrzegać dyscypliny, byliby narodem nie do pokonania.

Pan Payen zauważyl, że mieszkańcy Polski bywają zabobonni, czego przykłady odnajdıjeny w dziełach innych podróżników. Karol Ogier, będąc uczestnikiem uczty wydanej przez wojewodę ruskiego, miał możliwość skosztowania niezwykle smacznej potrawy z mięsa łosia, zwanego w Polsce magna bestia. Wojewoda obdarzyl posła francuskiego Klaudiusza de Mesmes racicą owego zwierzęcia, a stanowiła ona cenny podarunek ze względu na swe właściwości lecznicze ${ }^{33}$. K. Ogier zanotowal w swym dzienniku, iż racica odcięta zaraz po upolowaniu zwierzyny ma dobroczynną moc;

największy ona skutek sprawia, gdy bestia zabita jest in coitu albo przynajmniej w czasie rykowiska, to jest od św. Bartłomieja, jak to powiadają myśliwi ${ }^{3+}$.

Ulryk von Werdum zaś opisal tajemniczą chorobę Polaków, która według jego wiedzy „rozpowszechniła się w ostatuich trzydziestu, czterdziestu latach”35. Przypadłość owa, zwana koltunem ${ }^{36}$, wywolywala początkowo wielkie bóle glowy, a następnie wlosy zlepiały się i zrastały ,jakoby kapelusz pilśniowy ${ }^{37}$. Przesąd zabraniał obcinania koltuna z obawy przed utratą shuchu lub wzroku ${ }^{38}$, a powszechność tej choroby sprawiła, iż w Polsce można było spotkać „więcej ślepych niż w jakimkolwiek innyın kraju”"

Zdaniem Ulryka von Werdum, z zabobomością graniczyla nabożność Polaków, którzy podczas modlitwy upadali na zienię, uderzali glową o lawki i mur, bili się w twarz, głośno wzdychali, jęczeli i praktykowali ,inne w tym rodzaju dziwactwa, z których się papiści z innych narodów naśmiewają" " Równiez inne formy pobożności Polaków, takie jak niezwykle skrupulatne przestrzeganie postów, zdumiewaly przybysza z zagranicy. Zaobserwował

\footnotetext{
${ }^{32}$ Cudzoziemcy o Polsci..., op. cit., s. 296.

3.3 Fulwiusz Ruggieri, który w roku 1565 był nuncjuszem papieskim w Polsce, wcześniej poznal tajemniç niczwyklego lekarstwa. Wedhug jego relacji przeświadezenic o mocy owego leku wynikało z obserwacji chorego losia. który leczy swe przypadlości. drapiąc ucho nogą.

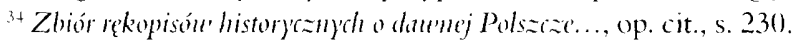

${ }^{35}$ Cudzozicmic) o Polsce.... op. cit., s. 292.

${ }^{3 k}$ Uważany niegdyś za polską chorobę narodową, nosi lacińską nazwç plica polonica.

${ }^{37}$ Cudzoziemcy' o Polsce...., op. cit.

${ }^{3 *}$ Etnograf Marian Udziela w pracy Medy'cyna i przesad ly leczllice ludu polskiego, wydanej w 1891 roku, pisze, iż wedke wierzeń hudowych w koltunie mieszkaly choroby, które atakowaly czlowicka po obcięciu wlosów. Na ten radykalny czyn decydowano siç zatem w określonycl okolicznościach: na czczo, w pogodny dzieni. lecz nigdy w piątek. Za najlepsze micjsca do przeprowadzenia tego zabiegu uważano Kalwarię Zebrzydowską i Kościól Mariacki w Krakowic. natomiast dnicm. w którym można było bezpiecznie obciąć koltun. byla Wiclka Sobota.

${ }^{3 \prime}$ Cudzoziemcy o Polsce.... op. cit.

t" Ibide'm.
} 
on, że mieszkańcy Polski w piątki nie jadali nie tylko mięsa, lecz także masła, sera, mleka i jaj, a potrawy z ryb i warzyw przygotowywali na oleju. Pościli także w imne dni „według przepisów rzymskiego kościola"t, jednak prawie wszyscy wyznaczali sobie dodatkowy dzień w tygodniu, kiedy powstrzymywali się od spożywania wyżej wymienionych potraw. Ulryk von Werdum odnotowal równiez fakt, iż „w lolsce w wilie świąt Panny Marii mięsa nie jadają, czego przecież u innych narodów nie obserwują"

Rzeczywiście, w dawnej Polsce bardzo rygorystycznie przestrzegano nakazu poszczenia w określone dni. Nie jadano mięsa i ograniczano inne pożywienie w środy, piątki i soboty, w czasie Adwentı, w Wiģiliç Bożego Narodzenia, w Środę Popielcową i Wielki Piątek. Postani poprzedzano także dni znanych patronów ${ }^{+3}$. Anna Zadrożyúska pisze, iż miało to na celı oczyszczenie z grzechów, whroczenic na drogę świętości, pozwalało też godnie uczestniczyć w święcie ${ }^{+t}$. Ten sposób okazywania pobożności przybierał jednak często skrajne formy, o czym świadczą spostrzeżenia cudzoziemców, iż Polacy „raczej dadzą się zabić, niż zlanią post" ${ }^{\prime 5}$. Eukasz Golębiowski w dzicle Lud polski, jego zu'yczaje i zabobony' podsumowat te obyczaje:

przed każdym wielkim świętem (...) czterdzieści dui poszczono (...). Nadto suchedni, krzyżowe dıi, wilic obchodzono i przyjçte dobrowolnic do Serca Jezusowego, Najświętszej Panny Bolesnej, św. Antoniego, św. Jana Nepomucena i innych świętych pięć, siedem albo dziewięć dıi postu, po jednym w kazdym tygodniu poprzedzającym. Suszono poniedziałki, środy, piątki, soboty, tak że czasem trzy dni tylko, u skrupulatniejszych za postami zaledwic dzicń jeden zostawal do mięsnych pokarmów (...). Nie dochować postı największym poczytywano grzechem $(\ldots)^{\text {to }}$.

Jean de Laboureur za zdumieniem przyglądał się także biczownikom, którzy podczas Wielkiego Tygodnia „calymi dniami i nocami suują się po kościołach” pro prówietle pochodni. Francuski historyk pisal:

Okryci są kapturami z otworani na oczy i habitami z białego lub czarnego ptótna, a na nich wymalowane piszczele ludzkie lub trupie głowy z napisem memento mori. (...) Padali potem plackiem na ziemię, całując swe krzyże,

\footnotetext{
${ }^{+1}$ lbide'm.

t? lbide'm.

\$3 Zob. A. Zadrożýnska. Suiçowania polskic. Warszawa 20012, s. 88-89.

+t Hidem, s.88.

th Cudzozicmo' "Polsce.... op. cit. s. 255.

th Cyt. za: A. Zadrozyniskil, op. cit., s. 89.

th Cudzozienty o Polsce... op. cit.
} 
a podnosząc się następnie, obnażali plecy i pedantycznie je chłostali w ciągu calego Miserere. Można bylo widzieć wielı takich, których rany dochodzily do głębokości palca. Rygory stosowane po wsiach przewyższały to, co działo się $\mathrm{w}$ miastach ${ }^{\text {t' }}$.

Przyznał on również, iż przerażały go przesądy Polaków, którzy trwali w przekonaniu, że biczowanie i zaniechanie jedzenia masła w czasie postu przyspieszy zbawienie ich dusz. Był też zdania, że pewne obyczaje praktykowane w Polsce podczas Mszy Świętej, takie jak bicie się w twarz w czasie Podniesienia, dowodzily przedkładania pozorów nad szczerą wiarę.

Z relacji cudzoziemców wynika zatem, że dostrzegali oni głęboką religijność mieszkańców Polski, jednak nick tóre jej przejawy budzily zdumienie przybyszów z Europy Zachodniej i w ich oczach świadczyly o przesądności Polaków oraz ich zamiłowaniu do teatralnych gestów.

Przybysze z zagranicy postrzegali Polaków jako ludzi, którzy nade wszystko cenią wolność, poza którą nie uznają ,innego pana" ${ }^{49}$. Karol Ogier z trudem dawal wiarę swobodzie, z jaką szlachta polska wyrażała swe myśli. Drugi sekretarz francuskiego ambasadora Klaudiusza de Mesmes ze zdumieniem odnotował, że Polacy bez najmniejszego skrępowania rozprawiali „o cesarzach i królach, a nawet o swoim wlasnym królu” ${ }^{\circ}$. Uznat on, iż wolność szlachecka w Polsce jest prawdziwie nieograniczona. Guillaume de Beauplan swoje spostrzeżenia na temat swobód, którymi cieszyła się szlachta polska, podsumował celną uwagą: „by więc stali się prawdziwymi suwerenami, brak im jeszcze tylko prawa bicia monet" ". Gaspar de Tende zanotował zaś, że każdy szlachcic jest wprawdzie zobowiązany do posłuszeństwa królowi, ale wyłącznie w ramach zagwarantowanej ustawami wolności, przywilejów i obietnic składanych przez wladcę podczas elekcji.

Ulryk von Werdum zauważal, że władza króla w Rzeczypospolitej jest w znacznym stopniu ograniczona, zatem musi on dążyć do wzmocnienia swej pozycji nie tyle przez stanowcze rozkazy, ile przez wykazanie się „politycznym rozumem” ${ }^{\text {"52 }}$. Przywolat on stowa Stefana Batorego, który zwykl mawiać, iż w Polsce król znaczy tyle, ile wart jest jego rozum.

Według relacji cudzoziemców „potomkowie Romulusa”, nazywani tak ze względu na powszechną znajomość łaciny, wyznawali równość wewnątrzstanową. Bystry obserwator mógł jednak dostrzec, tak jak Ulryk von Werdum, że owa równość miała charakter iluzoryczny, ponieważ polska szlachta była silnie zhierarchizowana. Dostrzegano też, iż szlachcice, uniżeni wobec potężniejszych i pełni kurtuazji wobec równych sobie, z arogancją traktują ludzi mniej znacznych od sicbie.

\footnotetext{
to Mbide'm.

+"Ibide'm. s. 275.

"Ibidem. s. 229.

5 Ilidem. s. 265.

Ibidem, s. 294.
} 
Uwage przybyszy z zagranicy zwracalo również nadmierne przywiązanie Polaków do tytułów i zwrotów grzecznościowych, zdmmiewal ich także swoisty kodeks postępowania, obowiązujący na przyklad podczas powitania. W drugie połowie XVI wicku owe tytuly, które szlachta stosowala miedzy sobą, były jeszcze zazwyczaj uproszczone ${ }^{53 .}$. Jednakże w XVII i XVIII wieku forma „pan” już nie wystarczała, dlatego zwracano się do siebie per „Waść, waszeć, waszmość, waszmość pan, miłościwy pan, wielmożny pan, jaśnie wielmożny, jaśnie oświecony" ". Sposób tytukowania się przez szlachtę odzwierciedlał jej wewnętrzne zróżnicowanie:

\begin{abstract}
Magnat zwracal się do podwładnego sobie szlachcica per „mości panie Kowalski", ten zaś pisal do magnata per ,jaśnie wielmożny panie a panie mnie wielce milościwy", dodając tytuły rodowe lub nazwy piastowanego przez adresata urzędı, określenia w rodzaju „dobrodzieju mój”, „oświecony” czy „laskawy”. W oficjalnej tytulaturze urzędowych akt spotykamy rozróżnienie "nobilis" (szlachetny) w odniesieniu do zamożniejszych i "generosus" (urodzony) w odniesieniu do uboższych ${ }^{55}$.
\end{abstract}

Spostrzeżenia cudzoziemców na ten temat mają zwykle charakter ironiczny. Henryk Michał I Iysrle, podsumowıjąc swój krótki pobyt w Polsce, zapisał, iż nigdzie tak „chłopom "Waszmościów» i “Mościpanów» nie nagadali", jak tutaj”. Fakt ten stal się dla czeskiego magnata i jego towarzyszy powoden do częstych kpin z takich zwyczajów. Ulryk von Werdum również zauważył sklonność Polaków do wzajemmego schlebiania sobic i prawienia komplementów, a swej relacji zanotowal z ironią:

nie ma ulicznego żebraka w Polsce, który by był tak nędzny, żeby go dzieci jego nie zwaly panem ojcem, a żonę jego panią matka ${ }^{57}$.

Podróżując po Polsce, obcokrajowcy dostrzegali bardzo wyraźnie, iż dumna polska szlachta "mieniła się być narodem” "ૅ̄" do którego nie wlączala mieszczan i chłopów. Polska struktura społeczna byla w odczuciu zagranicznych przybyszy zjawiskiem zgola egzotycznym, toteż zwykle oceniali ją krytycznie. Szczególnie razil ich stosunck szlachty do chło-

\footnotetext{
${ }^{33}$ Zob. J. Maciszcuski, Szladita polska i jej fanistuo. Warszawa 1980, s. 219.

${ }^{5+}$ Por.: "Nammożylo siç rozmaitych podstolich, stolników. fowczych, krajczych. powiatowych i ziemskich bez liku. kazdy z nich clıcial. by go tytulowano "jaśnic wichmożuym", jego syna krajezycem, podczaszycem i tak dalej. przy czym tyutuow ojcowskich uzywal syn az do śmicrci, jésli nie otrzymal whasnego tytulu" (ibide'm).

Ibidem, s. 221.

5" Cudzozicuncy" Polsce.... op. cit., s. 213.

Ibide'm, s. 297.

${ }^{5 n}$ J. Maciszewski, op. cit. s. 222.
} 
pów, którzy zgodnie ze słowami Galeazzo Marescottiego znajdowali się „w ciężkim jarzmie niewoli" ""'. Nuncjusz papieski, przebywający w Polsce w latach 1669-1671, z oburzeniem i współczuciem relacjonowal ich sytuację. Gaspar de Tende stwierdzil zaś, że szlachta traktowała chłopów jak niewolników, mieszczan zaś uważala za rzemieślników. Szlachcice polscy byli panami życia i śmierci chlopów, co uważal za przywilej sprzeczny z przesłaniem Ewangelii. Według Bernarda O'Connora, który w dużej mierze powolywał się na relację owego francuskiego szlachcica, naród polski dzielił się na dwa rodzaje ludzi: na szlachtę i chłopów, będących de facto niewolnikami, podobnie jak Murzyni w angielskich Indiach Zachodnich (1).

Już w połowie XVI wieku struktura społeczna Polski zwracała uwagę cudzoziemców, zdumionych jej odmiennością od tego, co znali z własnego doświadczenia. Wraz z uplywem czasu owa odmienność stale się nasilała, toteż stosunki społeczne panujące w Rzeczypospolitej postrzegane byly jako .,pozostałość czasów barbarzyńskich "(1).

Z relacji cudzoziemców wyłania się zatem obraz „póhnocnego kraju”, obdarzonego przez naturę wszystkim, co jest potrzebne do życia. Jego mieszkańcy jednak często nie wykorzystywali właściwie owych bogactw, dlatego bywali oceniani jako ludzie niedbali i nieskorzy do pracy. Tych, którzy odgrywali w Rzeczypospolitej największą rolę, cechowały odwaga i waleczność. choć potrafili być przy tym zuchwali i dumni, ponieważ nade wszystko cenili wolność. Z jednej strony byli gościnni i hojni, z drugiej zaś mieli skłonność do rozrzutności i marnotrawienia pieniędzy. Clę̧boko religijni, ale i zabobonni, budzili zdumienie zagranicznych podróżników niektórymi sposobami okazywania pobożności. Przywiązani do panıjących w ich kraju stosunków społecznych, nie dbali o to, iż w oczach cudzoziemców są one anachroniczne.

Jacy zatem byli naprawdę Polacy w XVII wieku?

Na podstawie spostrzeżeń cudzoziemców niełatwo byloby odpowiedzieć na to pytanie, wiele bowiem zależalo od tego, w jakim celu i o jakicj porze roku przybywali, kogo najczęściej spotykali na swojej drodze, jakie przejawiali sympatie polityczne. Nierzadko pojedyncze doświadczenia ksztaltowały ich całościowe spojrzenie na polską kulturę. Jej obraz, choć zapewne zdeformowany, jest jednak niekiedy prawdziwie frapujacy.

Cyt. za: J. A. Wilder, op. cit., s. 80.

"Zob. J. A. Wilder. op. cit., s. 90.

"Mbidem, s. 1+2. 